\title{
ATMOSPHERIC CONDITIONS ASSOCIATED WITH HIGH AND LOW OZONE CONCENTRATIONS IN THE LOWER TROPOSPHERE OVER THE AEGEAN SEA
}

\author{
KALABOKAS P.D.
}

\author{
Academy of Athens, Research Center for \\ Atmospheric Physics and Climatology \\ 84 Solonos str., 10680 Athens, Greece
}

Received: 07/12/12

Accepted: 29/04/13 *to whom all correspondence should be addressed: e-mail: pkalabokas@academyofathens.gr

\begin{abstract}
In this study the vertical ozone profiles during summertime (June to August) of the MOZAIC (Measurement of Ozone and Water Vapor by Airbus in Service Aircraft) Project over the eastern Mediterranean airports of Heraklion and Rhodes in the Aegean Sea, have been analyzed in order to identify the major factors determining the ozone variability in the lower troposphere over this area. In total 42 ozone profiles have been examined, which have been collected during a 10-year period (1996-2006). In addition, the corresponding vertical profiles of temperature, relative humidity, carbon monoxide and wind speed have been also examined in parallel. The vertical summer ozone profiles have been classified into groups of highest and lowest ozone levels in the free troposphere (at the $3000-5000 \mathrm{~m}$ and $1500-3000 \mathrm{~m}$ layers) and the corresponding composite weather maps of geopotential heights have been plotted and their examination was focused on the Aegean Sea area. From the data analysis it comes out that for the examined area, in the lower troposphere but also within the boundary layer the role of the synoptic weather conditions and the associated large-scale transport of air masses, especially anticyclonic subsidence, seem to be more important in understanding the ozone variability than the local or regional short-term ozone photochemical production.
\end{abstract}

KEYWORDS: Ozone, lower troposphere, meteorological conditions, Aegean Sea.

\section{INTRODUCTION}

It has been documented during the recent years that high rural background ozone levels, exceeding $60 \mathrm{ppb}$, have been observed in the lower troposphere and the boundary layer over mainland Greece, the Aegean Sea and other parts of the Eastern Mediterranean, especially during summertime (e.g. Varotsos et al., 1993; Kalabokas et al., 1996; Kalabokas and Bartzis 1998; Kalabokas et al., 2000; Kourtidis et al., 2002; Kouvarakis et al., 2002; Kalabokas and Repapis, 2004; Bossioli et al., 2007).

The weather conditions over the Eastern Mediterranean during summer are influenced by eastward extensions of the Azores anticyclone and the low pressure branch of the large South Asian thermal low. Modelling studies of the large-scale dynamics (Rodwell and Hoskins, 1996; Rodwell and Hoskins, 2001) also suggest a strong influence of the Indian Monsoon on the dry Mediterranean climate in summer, i.e. by Rossby wave interaction with the southern flank of the mid-latitude westerlies producing adiabatic descent and hence anticyclonic conditions at the surface over the Western Mediterranean. The resulting monsoon circulation over the Aegean Sea together with the strong pressure gradient, due to the surrounding mountains of the Greek peninsula in the West and the Anatolian plateau in the East, produces persistent northerly winds, the so called "Etesian winds" (annual winds). This flow of the low troposphere is most pronounced at the $850 \mathrm{hPa}$ level (Repapis 
et al., 1977). As a result, the Eastern Mediterranean is influenced by advection from Europe in the lower troposphere associated with the Etesian winds and subsidence in the middle and upper troposphere associated with the westerly flow in the descending branches of the Asian thermal low and, to a lesser extent, of the East African monsoon. It was also shown that the day-to-day variations in these two main factors are linked to the Asian monsoon (Rodwell and Hoskins 2001; Ziv et al., 2004).

The possibility for an influence of long-range pollution transport, mainly from the European continent, on ozone and its precursors over the Eastern Mediterranean has been discussed in several publications (Kallos, 1995; Lelieveld et al., 2002; Zerefos et al., 2002; Volz-Thomas et al., 2003). In addition, the prevailing synoptic weather conditions seem to influence significantly the ozone levels in the boundary layer but also in the lower troposphere (Kalabokas et al., 2007; 2008).

In a previous study derived from the same project, vertical ozone profiles measured in the period 1996-2002 in the framework of the MOZAIC (Measurement of Ozone and Water Vapor by Airbus in Service Aircraft) project (Marenco et al., 1998) for flights connecting Central Europe to the Eastern Mediterranean basin (Heraklion, Rhodes, Antalya) have been analyzed (Kalabokas et al., 2007). The 77 flights during summer (JJAS) showed over the Eastern Mediterranean significantly (10-12 ppb, $20-40 \%$ ) enhanced ozone mixing ratios in the lower troposphere and especially at the $1000-700$ $\mathrm{hPa}$ layer, where ozone frequently exceeds the $60 \mathrm{ppb}, 8-\mathrm{h}$ EU air quality standard, whereas ozone between 700 and $400 \mathrm{hPa}$ was only slightly (3-5 ppb, 5-10\%) higher than over Central Europe. Analysis of composite weather maps for the high and low ozone cases within the boundary layer (at the $900 \mathrm{hPa}$ level), as well as back-trajectories and vertical profiles of carbon monoxide, suggest that the main factor leading to high tropospheric ozone values in the area is anticyclonic influence, in combination with a persistent northerly flow in the lower troposphere and the boundary layer during summertime over the Aegean Sea. On the other hand, the lowest ozone levels are associated with the passing of low-pressure systems or the extension to the west of the Middle-East low associated with weak pressure gradients over the Eastern Mediterranean and an upper air trough in the North Eastern Europe. The same pattern of summer ozone variability has been observed by analyzing the ozone measurements at several rural sites in the Eastern and Central Mediterranean (Kalabokas et al., 2008), showing that the highest and lowest summer afternoon ozone levels are strongly associated with characteristic synoptic meteorological conditions prevailing throughout the whole lower troposphere.

The aim of this work is to investigate the meteorological and/or chemical factors controlling the lower troposphere ozone levels, above the boundary layer (1.5-5 km altitude) over the Aegean Sea, having in mind also that the outcome of this investigation will lead to a better understanding of the ozone variations observed inside the boundary layer as well as at the surface of the examined region. For this purpose, vertical MOZAIC summer ozone profiles measured in the period 1996-2006 over the Aegean Sea airports of Heraklion and Rhodes were analyzed in order to identify the atmospheric conditions associated with high and low ozone levels in the lower troposphere. Also, the measurements of relative humidity, temperature, wind speed and carbon monoxide have been examined in parallel with the ozone measurements. In this respect, vertical profiles of the above mentioned parameters collected during days with very high or very low ozone mixing ratios in the lower troposphere have been examined together with the corresponding composite weather maps.

\section{DATA AND METHODOLOGY}

Vertical MOZAIC (Measurement of Ozone and Water Vapor by Airbus in Service Aircraft; Marenco et al., 1998) profiles (42 in total) from ascending and descending flights over the Aegean airports of Heraklion $\left(35.3^{\circ} \mathrm{N}, 25.2^{\circ} \mathrm{E}\right)$ and Rhodes $\left(36.4^{\circ} \mathrm{N}, 28.1^{\circ} \mathrm{E}\right)$ have been analyzed $(1996-2006)$. Measurements are taken from take-off to landing. Based on the dual-beam UV absorption principle (Thermo-Electron, Model 49-103), the ozone measurement accuracy is estimated at \pm [2 ppbv $+2 \%]$ for a 4 s response time (Thouret et al., 1998). Based on an infrared analyzer, the carbon monoxide measurement accuracy is estimated at \pm 5 ppbv $\pm 5 \%$ (Nédélec et al., 2003) for a $30 \mathrm{~s}$ response time. The analysis is focused on summertime (June to August) profiles. The studied parameters are: Ozone, relative humidity, carbon monoxide, temperature and wind speed. The set of collected profiles is classified into groups of $10 \%$ highest and $10 \%$ lowest ozone levels for two vertical layers in the lower free troposphere over the Aegean Sea (1500-3000m and 3000-5000m). 


\section{RESULTS AND DISCUSSION}

The examination of the averaged vertical summer ozone profiles over Heraklion and Rhodes for the $10 \%$ highest and the $10 \%$ lowest ozone mixing ratios in the free troposphere, at the $3000-5000 \mathrm{~m}$ and 1500-3000 m levels, in parallel with the corresponding curves of relative humidity, carbon monoxide, vertical temperature gradient and wind speed (Figures 1 and 2 respectively), shows the following: The $10 \%$ highest ozone concentrations at 3000-5000 m and 1500-3000 m height levels over Heraklion and Rhodes are associated with low values of relative humidity, vertical temperature gradient and wind speed in these layers, indicating anticyclonic atmospheric conditions linked with subsidence of air masses from the upper troposphere. On the other hand, the $10 \%$ lowest ozone concentrations at 3000-5000 m and 1500-3000 m over the examined Aegean airports are associated with high values of relative humidity, vertical temperature gradient and wind speed, indicating vertical instability and ascending movements of air masses. It is remarkable that, to the contrary of the large ozone and relative humidity differences in the lower troposphere, the average $\mathrm{CO}$ levels observed over Heraklion and Rhodes are comparable between the highest and lowest ozone days over the examined airports. This indicates comparable levels of primary pollution in the air masses under both examined conditions (highest-lowest ozone). It has to be reminded that because of its low solubility and its photochemical lifetime of the order of weeks, carbon monoxide (CO) is a good tracer of anthropogenic pollution and $\mathrm{CO}$ profiles have been used for tracking pollution episodes in the boundary layer or even in the free troposphere (Nédélec et al., 2003).

In Figure 3 the composite weather maps of geopotential heights at at $700 \mathrm{hPa}$ of the $10 \%$ of the days with the highest ozone and $10 \%$ of the days with the lowest ozone concentrations (at the 1500$3000 \mathrm{~m}$ layer) are plotted. The composite weather maps were constructed from the NCEP/NCAR reanalysis, based on grids of $2.5 \times 2.5 \mathrm{deg}$, for the days of the flights in each group following the procedure of Kalnay et al. (1996). It is observed that the highest ozone concentrations in the lower troposphere (but also in the boundary layer at the same time) occur, in fact, during high pressure (anticyclonic) conditions prevailing over North-Africa and the Mediterranean Sea as well as over parts of Western Europe. The Greek peninsula and the Aegean Sea are under the influence anticyclonic flow, which, as previously mentioned, is mainly linked with transport and subsidence of air masses from the upper troposphere leading to increase in ozone and decrease in relative humidity as it is well known that the upper tropospheric air is richer in ozone and poorer in relative humidity. On the other hand, the lowest ozone values are associated with the presence of lowpressure systems influencing the examined area and leading to strong westerly circulation over the Mediterranean towards the eastern region. These low pressure (cyclonic) conditions, are associated with high dispersion and uplifting of boundary layer air towards the lower troposphere (in association with the important summer thermal convection in the area) leading to decrease in ozone and increase in relative humidity (boundary layer air masses are poorer in ozone and richer in relative humidity in comparison to tropospheric air masses). These observations are in agreement with the results of previous research investigations in the Aegean Sea and the Eastern Mediterranean, focusing primarily to the boundary layer (Kalabokas et al., 2007; 2008). An additional detail concerning the lower tropospheric weather conditions is that at the $700 \mathrm{hPa}$ level and during the highest ozone days the quasi-permanent anticyclone usually located over Northwestern Africa is stronger and more extended especially towards Western Europe, if compared to the meteorological situation observed during the lowest ozone days when the anticyclone is significantly weaker (Figure 3). This strengthening and expansion of the North-African anticyclone seems to be a critical factor associated with the anticyclonic influence over Greece and the Aegean Sea. On the other hand, during the lowest ozone days the North-African anticyclone is weaker and less extended towards the European continent while at the same time the examined area is under the influence of the low pressure systems moving to Greece and the Aegean Sea from Northern and Central Europe (Figure 3).

It has also to be mentioned that the characteristic synoptic weather patterns, corresponding to highest and lowest ozone, are extended throughout the lower troposphere, from the ground level to at least $5 \mathrm{~km}$, as it comes out also from the examination of composite weather maps at 850 and 500 $\mathrm{hPa}$ (not shown). In addition, these meteorological patterns are present in the atmosphere for some days before the selected measurement, especially for the highest ozone days, as shown in Figure 3. 


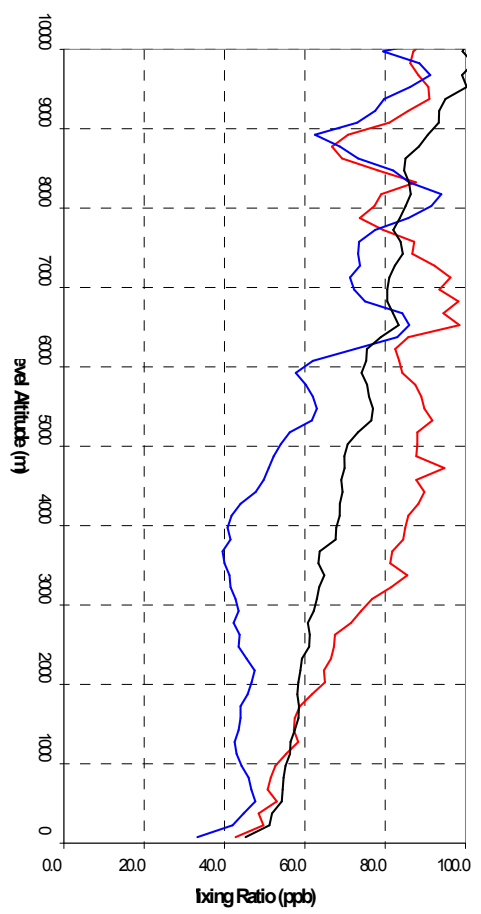

OZONE

(a)

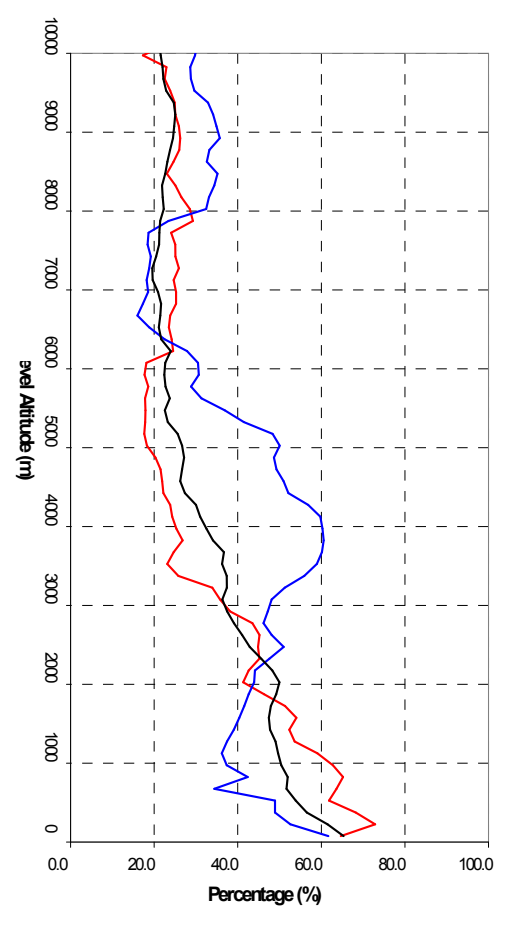

(b)

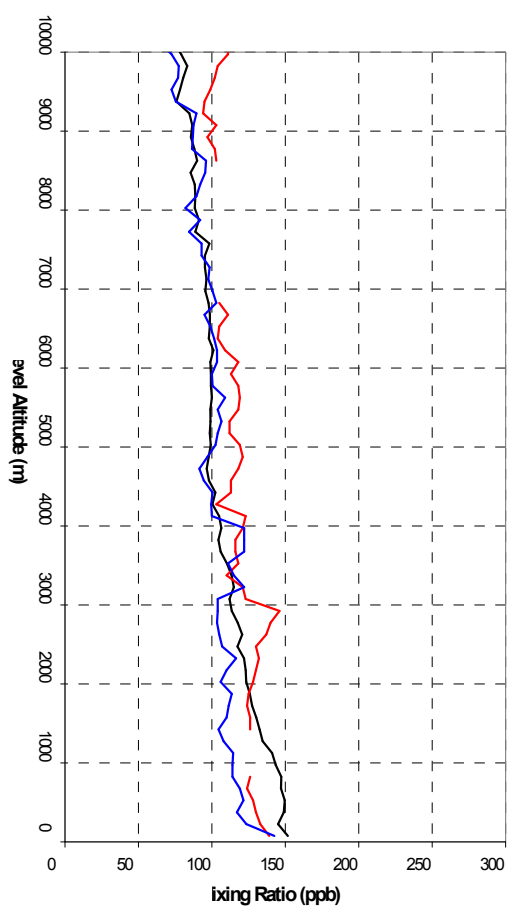

co

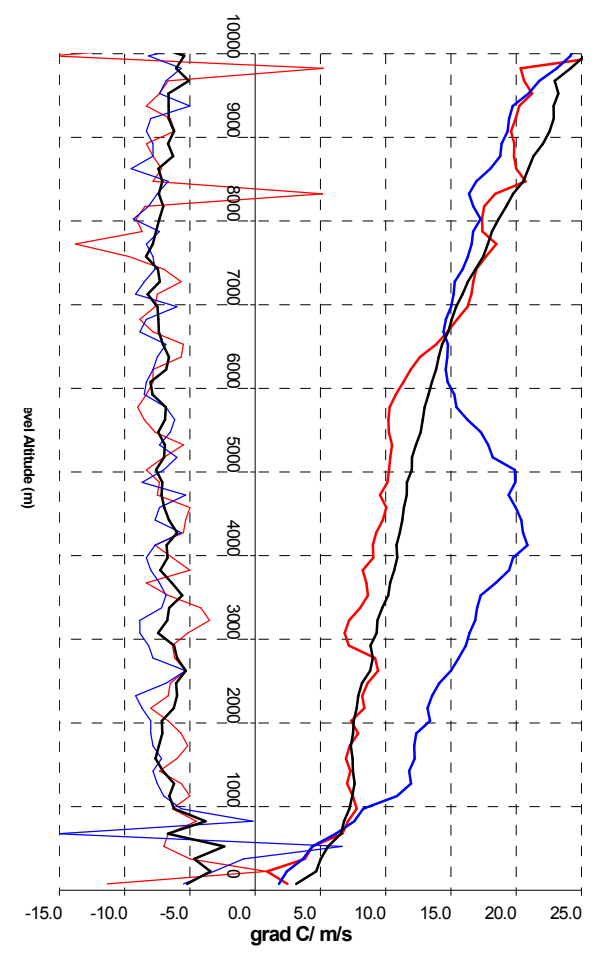

EMPERATURE GRADIENT per KM / MND SPEED

(d)

Figure 1. (a).The averaged vertical summer (JJA) ozone profiles over the Aegean airports of Heraklion and Rhodes for the $10 \%$ highest (red line) and the 10\% lowest (blue line) ozone mixing ratios at 3000-5000 m, (b). Same as (a) but for relative humidity, (c). Same as (a) but for carbon monoxide (CO), (d). (Left), Same as (a) but for temperature gradient per km, (Right), Same as (a) but for wind speed. The bold line in (a), (b), (c), (d) shows the mean profile of the respective parameter (all profiles included) 


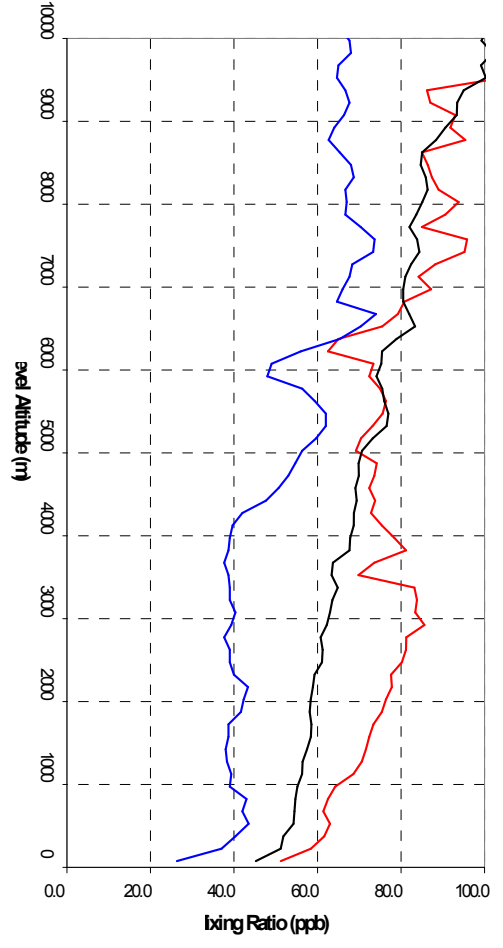

OZONE

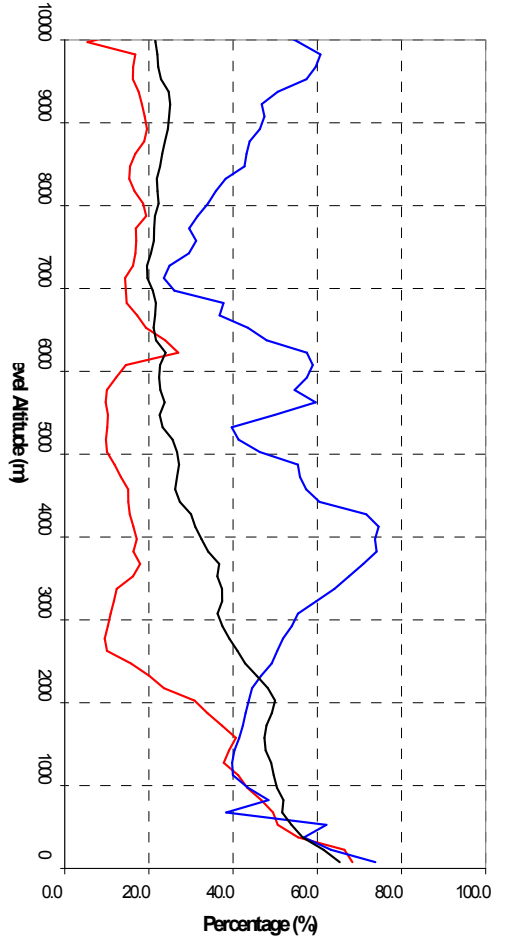

EATIVEHMDTY

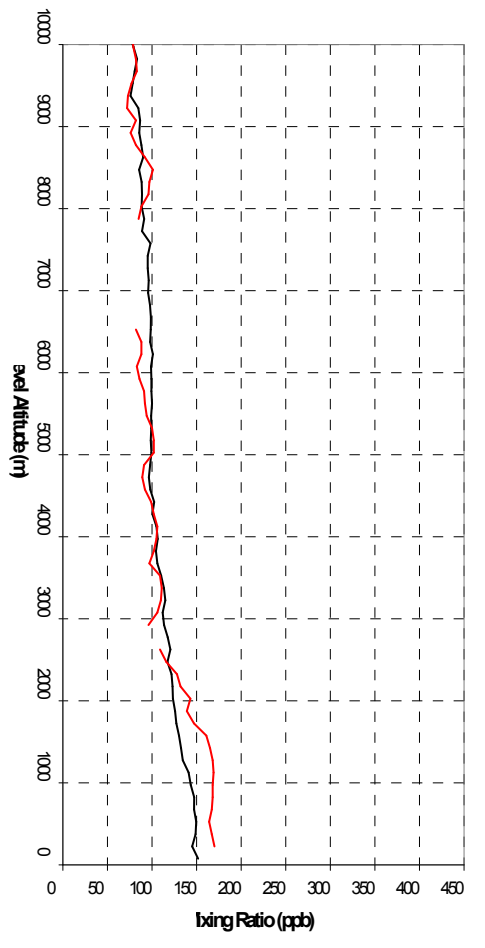

$\infty$

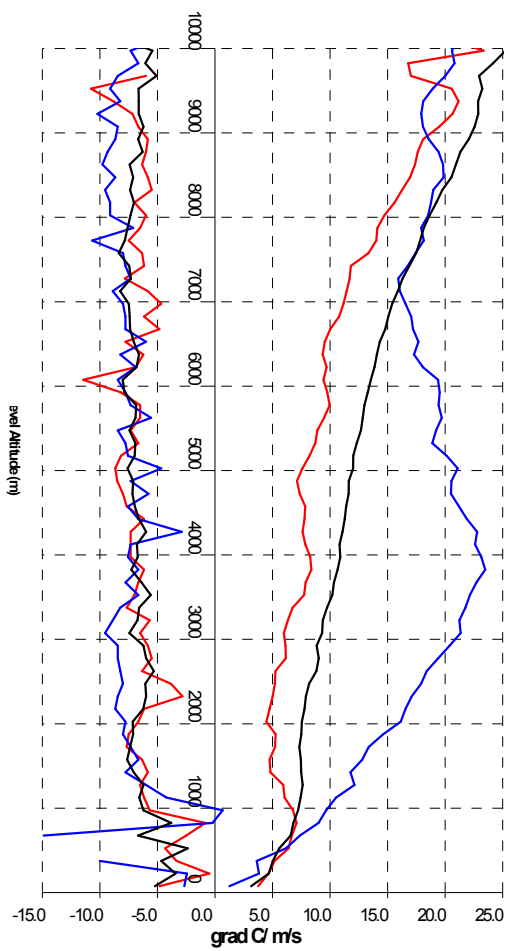

ENPERATURE GRADIENT Per KM/ WNDSPEFD

(a)

(c)

(d)

Figure 2. (a). The averaged vertical summer (JJA) ozone profiles over the Aegean airports of Heraklion and Rhodes for the 10\% highest (red line) and the $10 \%$ lowest (blue line) ozone mixing ratios at 1500-3000 m, (b). Same as (a) but for relative humidity, (c). Same as (a) but for carbon monoxide (CO), (d). (Left), Same as (a) but for temperature gradient per km, (Right), Same as (a) but for wind speed. The bold line in (a), (b), (c), (d) shows the mean profile of the respective parameter (all profiles included) 


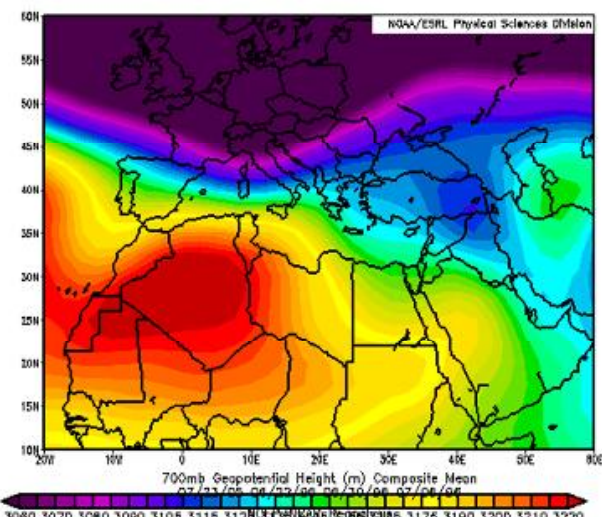

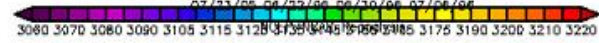

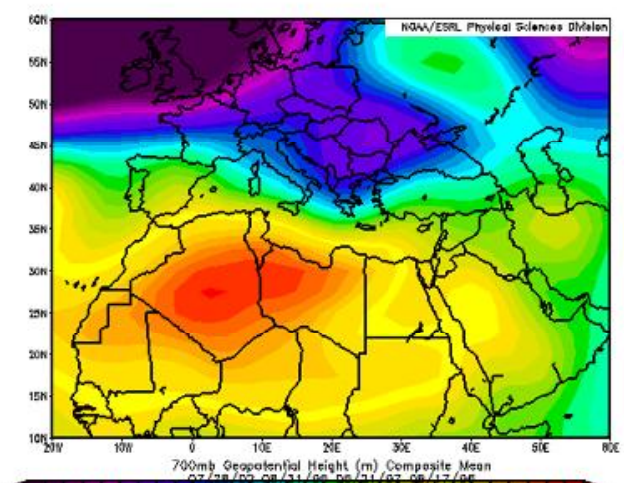

3050307030803080310531153128 अ

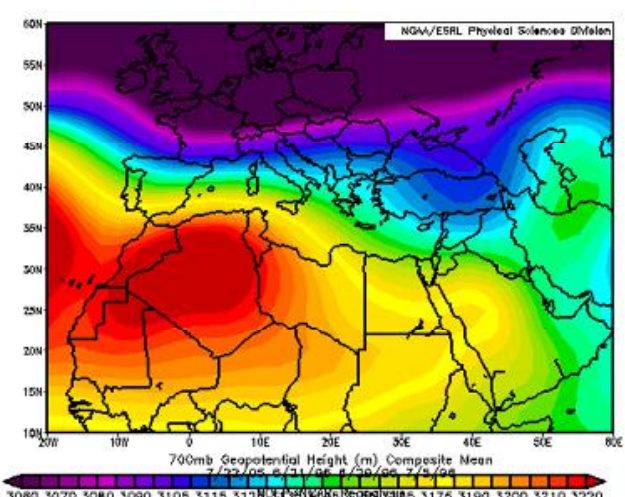

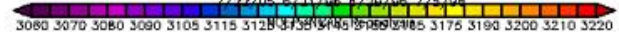
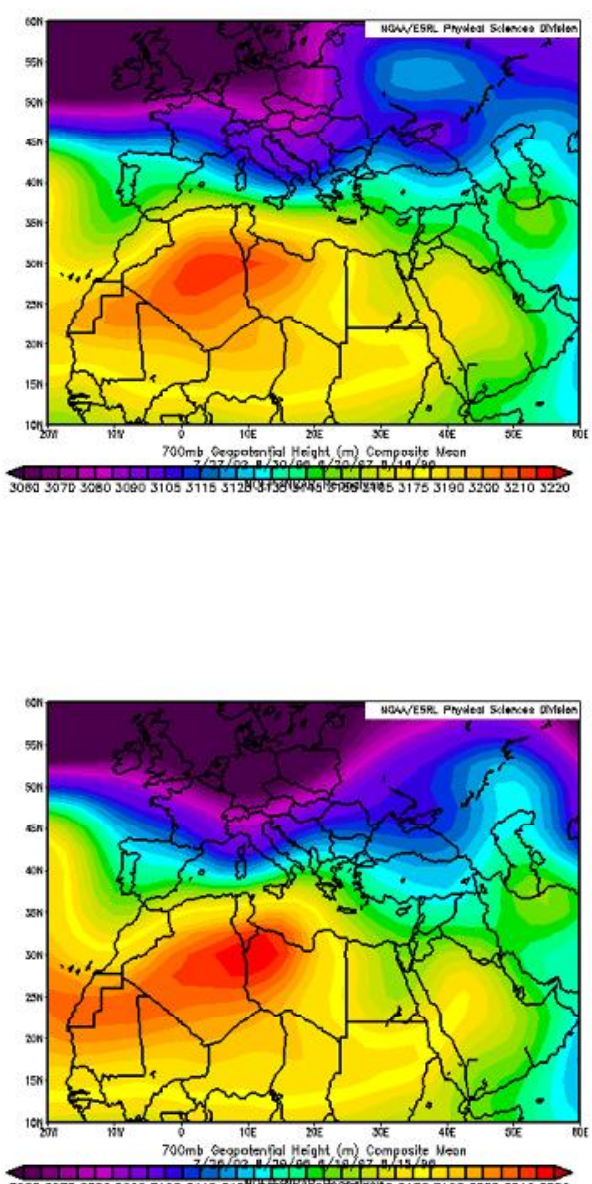

Figure 3. Composite weather maps of geopotential heights at $700 \mathrm{hPa}$ of the $10 \%$ of the days with the highest ozone concentrations at the 1500-3000 m layer (left column) and of the $10 \%$ of the days

with the lowest ozone concentrations at the 1500-3000 m layer (right column) in Heraklion and Rhodes during the day of the measurement ( $1^{\text {st }}$ row), 1 -day before the measurement $\left(2^{\text {nd }}\right.$ row), and 2-days before the measurement ( $3^{\text {rd }}$ row). 
From this analysis it comes out that a key factor leading to high ozone values in the lower troposphere over the Eastern Mediterranean is the anticyclonic influence. As mentioned, summer anticyclones are rich in ozone as they transport downwards the upper troposphere ozone, which has a marked midsummer peak over Europe (Thouret et al., 2006). In addition, it has to be noted that similar observations of high ozone levels during anticyclonic conditions have been reported also at rural sites in Western and Central Mediterranean following the analysis of surface ozone data (Sánchez et al., 2008; Schürmann et al., 2009; Velchev et al., 2011). It seems though that this phenomenon is even more pronounced in the Eastern Mediterranean region where atmospheric conditions of strong summer anticyclonic subsidence in the lower troposphere, leading to high ozone concentrations, have been reported recently as a result of analysis of satellite data as well as large scale atmospheric modelling simulations, which is in agreement with our observations (Eremenko et al., 2008; Foret et al., 2009; Liu et al., 2009; Coman et al., 2012).

According to the above, high levels of tropospheric ozone are accumulated on the top of the boundary layer when the Greek peninsula and the Aegean Sea are under the influence of anticyclonic synoptic weather conditions. Depending on the meteorological conditions, the time of the day and the particular geographical characteristics of each site in the area (e.g. mountains ranges, sea-breeze cells), ozone-rich tropospheric air may enter the boundary layer causing fumigation and resulting to high surface ozone levels, which might exceed the air quality standards, like for example the $60 \mathrm{ppb}$ EU standard for human health protection. Similar field observations regarding the influence of lower troposphere ozone to the boundary layer and surface measurements have been reported recently at some locations of the Californian coast (Parrish et al., 2010).

From the above analysis, it comes out that especially in the lower troposphere but also within the boundary layer the role of the synoptic weather conditions and the associated large-scale transport of air masses, rich or poor in ozone, seem to be more important in understanding the ozone variability than the local short-term ozone photochemical production, for the examined Aegean Sea area. The above remarks should have implications in the formulation of the air pollution abatement strategies in the urban centers of the region under study. It should be taken into account that the 60 ppb EU standard for human health protection could be relatively frequently exceeded in the area during case events when the ground surface ozone concentrations are influenced by subsidence of air masses from the upper troposphere.

\section{CONCLUSIONS}

The analysis of the vertical summer ozone profiles measured in the period 1996-2006 in the framework of the MOZAIC project over the Eastern Mediterranean airports of Heraklion and Rhodes, shows that the highest ozone levels in the lower troposphere over the examined Eastern Mediterranean airports are associated with low relative humidity, low vertical temperature gradient and low wind speed. These measurements correspond to prevailing anticyclonic synoptic meteorological conditions. Summer mid-latitude anticyclones influence boundary layer and surface ozone primarily by downward transport from the upper troposphere but also by creating stable conditions close to the surface, thereby hindering vertical dispersion of ozone precursors and enabling them to travel over long distances horizontally thus leading to regional photochemical activity in the boundary layer. On the other hand, the lowest ozone levels are associated with high relative humidity, high vertical temperature gradient and high wind speed and occur during low pressure (cyclonic) meteorological conditions. A remarkable observation during the present investigation is that in the lower troposphere $(1500-5000 \mathrm{~m})$ the CO levels do not differ substantially between the highest and lowest ozone days, which means that the high differences in tropospheric ozone (40-45 ppb) occur despite the comparable primary pollution levels in both examined situations, indicating the meteorological factor as predominant in controlling the tropospheric ozone levels, if compared to the local photochemistry over the examined region. The accumulation of high ozone levels due to tropospheric subsidence on the top of the boundary layer might influence significantly the surface ozone concentrations, when the meteorological conditions are favorable, which should be taken into account during the formulation of local photochemical pollution abatement strategies. 


\section{ACKNOWLEDGEMENTS}

The MOZAIC Project was funded by the European Commission. The main operators of MOZAIC (Dr. J.-P. Cammas and Dr. V. Thouret, Laboratoire d'Aerologie, CNRS and Universite de Toulouse, France, as well as Dr. A. Volz-Thomas - Forschugszentrum Juelich, Germany) are gratefully acknowledged for providing data and useful discussions. Dr. C. Repapis (Academy of Athens and Mariolopoulos-Kanaginis foundation) is also acknowledged for helpful discussions and comments on the manuscript.

\section{REFERENCES}

Bossioli E., Tombrou M., Dandou A. and Soulakellis N. (2007) Simulation of the effects of critical factors on ozone formation and accumulation in the Greater Athens Area, J. Geophys. Res., 112(D2), doi:10.1029/2006JD007185.

Coman A., Foret G., Beekmann M., Eremenko M., Dufour G., Gaubert B., Ung A., Schmechtig C., Flaud J.-M. and Bergametti G. (2012) Assimilation of IASI partial tropospheric columns with an Ensemble Kalman Filter over Europe, Atmos. Chem. Phys., 12, 2513-2532.

Eremenko M., Dufour G., Foret G., Keim C., Orphal J., Beekmann M., Bergametti G. and Flaud J.-M. (2008) Tropospheric ozone distributions over Europe during the heat wave in July 2007 observed from infrared nadir spectra recorded by IASI, Geophys. Res. Lett., 35, doi:10.1029/2008GL034803.

Foret G., Hamaoui L., Schmechtig C., Eremenko M., Keim C., Dufour G., Boynard A., Coman A., Ung A. and Beekmann M. (2009) Evaluating the potential of IASI ozone observations to constrain simulated surface ozone concentrations, Atmos. Chem. Phys., 9, 8479-8491, doi:10.5194/acp-9-8479-2009.

Kalabokas P., Amanatidis G. and Bartzis J. (1996) Rural ozone levels at an Eastern Mediterranean site (Attica, Greece). In: Bojkov, R., Visconti, G. (Eds.), Proceedings of the XVIII Quadrennial Ozone Symposium. L'Aquila, Italy, pp. 379-382.

Kalabokas P.D. and Bartzis J.G. (1998) Photochemical air pollution characteristics at the station of the NCSR-Demokritos, during the MEDCAPHOT-TRACE campaign, Greece (August 20thSeptember 20th, 1994), Atmosph. Environ., 32(12), 2123-2139.

Kalabokas P.D., Viras L.G., Bartzis J.G. and Repapis C.C. (2000) Mediterranean rural ozone characteristics around the urban area of Athens, Atmosph. Environ., 34(29-30), 5199-5208.

Kalabokas P.D. and Repapis C.C. (2004) A climatological study of rural surface ozone in Central Greece, Atmos. Chem. Phys., 4, 1139-1147.

Kalabokas P.D., Volz-Thomas A., Brioude J., Thouret V., Cammas J-P. and Repapis C.C. (2007) Vertical ozone measurements in the troposphere over the Eastern Mediterranean and comparison with Central Europe, Atmos. Chem. Phys., 7, 3783-3790.

Kalabokas P.D., Mihalopoulos N., Ellul R., Kleanthous S. and Repapis C.C. (2008) An investigation of the meteorological and photochemical factors influencing the background rural and marine surface ozone levels in the central and eastern Mediterranean, Atmos. Environ., 42, 78947906.

Kallos G. (1995) Transport and transformation of air pollutants from Europe to the east Mediterranean region. Progress report, contract AVI-CT92-0005. European Commission on Environmental Research Programme Avicenne, Brussels.

Kalnay E., Kanamitsu M., Kistler R., Collins W., Deaven D., Gandin L., Iredell M., Saha S., White G., Woolen J., Zhu Y., Chelliah M., Ebisuzaki W., Higgins W., Janowiak J., Mo K. C. Ropelewski C., Wang J., Leetmaa A., Reynolds R., Jenne R. and Joseph D (1996) The NCEP/NCAR Reanalysis 40-year Project, Bull. Amer. Meteor. Soc., 77, 437-471.

Kourtidis K., Zerefos C., Rapsomanikis S., Simeonov V., Balis D., Perros P.E., Thomson A.M., Witte J., Calpini B., Sharobiem W.M., Papayannis A., Mihalopoulos N. and Drakou R. (2002) Regional levels of ozone in the troposphere over eastern Mediterranean, J. Geoph. Res., 107(D18), doi:10.1029/2000JD000140.

Kouvarakis G., Vrekoussis M., Mihalopoulos N., Kourtidis K., Rappenglueck B., Gerasopoulos E. and Zerefos C. (2002) Spatial and temporal variability of tropospheric ozone in the boundary layer above the Aegean Sea (eastern Mediterranean), J. Geoph. Res., 107(D18), PAU 4-1 PAU 4-14, doi:10.1029/2000JD000081. 
Lelieveld J., Berresheim H., Borrmann S., Crutzen P.J., Dentener F.J., Fischer H., de Gouw J., Feichter J., Flatau P., Heland J., Holzinger R., Korrmann R., Lawrence M., Levin Z., Markowicz K., Mihalopoulos N., Minikin A., Ramanathan V., de Reus M., Roelofs G.-J., Scheeren H.A., Sciare J., Schlager H., Schultz M., Siegmund P., Steil B., Stephanou E., Stier P., Traub M., Williams J. and Ziereis H., (2002) Global air Pollution crossroads over the Mediterranean, Science, 298, 794-799.

Liu J.J., Jones D.B.A., Worden J.R., Noone D., Parrington M. and Kar J. (2009) Analysis of the summertime build-up of tropospheric ozone abundances over the Middle East and North Africa as observed by the Tropospheric Emission Spectrometer instrument, J. Geophys. Res., 114(D05), doi:10.1029/2008JD010993.

Marenco A., Thouret V., Nedelec P., Smit H., Helten M., Kley D,. Karcher F., Simon P., Law K., Pyle J., Poschmann G., Von Wrede R., Hume C. and Cook T. (1998) Measurements of ozone and water vapor by Airbus in-service aircraft: The MOZAIC airborne program, An overview, J. Geophys. Res., 103, 25631-25642.

Nédélec P., Cammas J.-P., Thouret V., Athier G., Cousin J.-M., Legrand C., Abonnel C., Lecoeur F., Cayez G. and Marizy C. (2003) An improved infrared carbon monoxide analyser for routine measurements aboard commercial Airbus aircraft: technical validation and first scientific results of the MOZAIC III programme, Atmos. Chem. Phys., 3, 1551-1564.

Parrish D.D., Aikin K.C., Oltmans S.J., Johnson B.J., Ives M. and Sweeny C. (2010) Impact of transported background ozone inflow on summertime air quality in a California ozone exceedance area, Atmos. Chem. Phys., 10, 10093-10109.

Repapis C., Zerefos C. and Tritakis B. (1977) On the Etesians over the Aegean, Proc. Acad. Athens, $52,572-606$.

Sánchez M.L., García M.A., Pérez I.A. and de Torre B. (2008) Evaluation of surface ozone measurements during 2000-2005 at a rural area in the upper Spanish plateau, J. Atmosph. Chem., 60, 137-152.

Schürmann G.J., Algieri A., Hedgecock I.M., Manna G., Pirrone N. and Sprovieri F. (2009) Modelling local and synoptic scale influences on ozone concentrations in a topographically complex region of Southern Italy, Atmosph. Environ., 43, 4424-4434.

Rodwell M.J. and Hoskins B.J. (1996) Monsoons and the dynamics of deserts, Q.J.R. Meteorol. Soc., 122, 1385-1404.

Rodwell M.J. and Hoskins B.J. (2001) Subtropical anticyclones and summer monsoons, J. of Climate, 14, 3192-3211.

Thouret V., Marenco A., Logan J., Nédélec P. and Grouhel C. (1998) Comparisons of ozone measurements from the MOZAIC airborne program and the ozone sounding network at eight locations, J. Geophys. Res., 103, 25 695-25 720.

Thouret V., Cammas J.-P., Sauvage B., Athier G., Zbinden R., Nédélec P., Simon P. and Karcher F. (2006) Tropopause referenced ozone climatology and inter-annual variability (1994-3003) from the MOZAIC programme, Atmos. Chem. Phys., 6, 1033-1051.

Varotsos C., Kalabokas P. and Chronopoulos G. (1993) Atmospheric ozone concentration at Athens, Greece. Part II: Vertical ozone distribution in the troposphere, Atmosph. Res., 30, 151-155.

Velchev K., Cavalli F., Hjorth J., Marmer E., Vignati E., Dentener F. and Raes F. (2011) Ozone over the Western Mediterranean Sea - results from two years of shipborne measurements, Atmos. Chem. Phys., 11, 675-688.

Volz-Thomas A., Beekmann M., Derwent D., Law K., Lindskog A., Prevot A., Roemer M., Schultz M., Schurath U., Solberg S. and Stohl A. (2003) Tropospheric Ozone and its Control, In: Towards Cleaner Air for Europe - Science, Tools and Applications, Pt 1, Results from the EUROTRAC-2; Synthesis and Integration (S\&I) Project, Builtjes, P. J.-H., Harrison, R. M., Midgley, P. M., and Tørsen, K. (Eds.), International Scientific Secretariat, Munchen, Germany, 73-122, 2003.

Zerefos C.S., Kourtidis K.A., Melas D., Balis D., Zanis P., Katsaros L., Mantis H.T., Repapis C., Isaksen I., Sundet J., Herman J,. Bhartia P.K. and Calpini B. (2002) Photochemical Activity and Solar Ultraviolet Radiation (PAUR) Modulation factors: An overview of the project, J. Geophys. Res., 107(D18), PAU1-1 - PAU1-15, doi:10.1029/2000JD00134.

Ziv B., Saaroni H. and Alpert P. (2004) The factors governing the summer regime of the Eastern Mediterranean, Int. J. Climatol., 24, 1859-1871. 